\title{
Evaluation of optimum roughage to concentrate ratio in maize stover based complete rations for efficient microbial biomass production using in vitro gas production technique
}

\author{
Y. Ramana Reddy ${ }^{1}$, N. Nalini Kumari², T. Monika² and K. Sridhar ${ }^{2}$
}

1. Department of Animal Nutrition, College of Veterinary Science, Kadapa - 516 360, Andhra Pradesh, India;

2. Department of Animal Nutrition, College of Veterinary Science, Hyderabad - 500 030, Telangana, India.

Corresponding author: Y. Ramana Reddy, e-mail: ramanayr19@yahoo.co.in,

NNK: nalini_reddy123@yahoo.co.in, TM: tmonika123@yahoo.co.in, KS: sri.vety@gmail.com

Received: 20-01-2016, Accepted: 10-05-2016, Published online: 19-06-2016

doi: 10.14202/vetworld.2016.611-615 How to cite this article: Ramana Reddy Y, Nalini Kumari N, Monika T, Sridhar K (2016) Evaluation of optimum roughage to concentrate ratio in maize stover based complete rations for efficient microbial biomass production using in vitro gas production technique, Veterinary World, 9(6): 611-615.

\begin{abstract}
Aim: A study was undertaken to evaluate the optimum roughage to concentrate ratio in maize stover (MS) based complete diets for efficient microbial biomass production (EMBP) using in vitro gas production technique.

Materials and Methods: MS based complete diets with roughage to concentrate ratio of 100:0, 90:10, 80:20, 70:30, 60:40, 50:50, 40:60, and 30:70 were formulated, and $200 \mathrm{mg}$ of oven-dried sample was incubated in water bath at $39^{\circ} \mathrm{C}$ along with media (rumen liquor [RL] - buffer) in in vitro gas syringes to evaluate the gas production. The gas produced was recorded at 8 and $24 \mathrm{~h}$ of incubation. In vitro organic matter digestibility (IVOMD), metabolizable energy (ME), truly digestible organic matter (TDOM), partitioning factor (PF), and EMBP were calculated using appropriate formulae. Ammonia nitrogen and total volatile fatty acids (TVFAs) production were analyzed in RL fluid-media mixture after $24 \mathrm{~h}$ of incubation.
\end{abstract}

Results: In vitro gas production (ml) at $24 \mathrm{~h}$ incubation, IVOMD, ME, TDOM, TVFA concentration, and ammonia nitrogen production were increased $(\mathrm{p}<0.01)$ in proportion to the increase in the level of concentrate in the diet. Significantly $(\mathrm{p}<0.01)$ higher PF and EMBP was noticed in total mixed ration with roughage to concentrate ratio of 60:40 and 50:50 followed by $70: 30$ and 40:60.

Conclusion: Based on the results, it was concluded that the MS can be included in complete rations for ruminants at the level of 50-60\% for better microbial biomass synthesis which in turn influences the performance of growing sheep.

Keywords: complete ration, in vitro gas technique, maize stover, roughage to concentrate ratio.

\section{Introduction}

The livestock industry is an important sector in the developing countries of Asia and Africa, and it provides income for small-scale farmers in addition to those generated from agriculture. Although the livestock population is high in developing countries, the production level per head is lower compared to developed countries. This is mainly due to shrinkage of grazing land which indirectly affects the ability of small and marginal scale farmers to feed animals adequately throughout the year [1]. To overcome such problems, we need to develop another alternate economic feeding system. Incorporation of locally available crop residues (CR), such as cereal straws and stovers, in the form of the complete ration, is an alternative plausible option for ruminant feeding because the blend of unpalatable roughages and concentrates offers little choice to the animal selection of specific ingredients in feed [2]. Moreover, optimization of

Copyright: Reddy, et al. Open Access. This article is distributed under the terms of the Creative Commons Attribution 4.0 International License (http://creativecommons.org/licenses/by/4.0/), which permits unrestricted use, distribution, and reproduction in any medium, provided you give appropriate credit to the original author(s) and the source, provide a link to the Creative Commons license, and indicate if changes were made. The Creative Commons Public Domain Dedication waiver (http://creativecommons.org/ publicdomain/zero/1.0/) applies to the data made available in this article, unless otherwise stated. roughage $(\mathrm{R})$ to concentrate $(\mathrm{C})$ ratio $(\mathrm{R}: \mathrm{C})$ improves the efficiency of nutrient utilization. In addition to this, an optimum level of roughage supplementation is essential in ruminant diets to maintain the desirable volatile fatty acids (VFA) production pattern.

Cereal CR are an important feed source for ruminants in smallholders crop-livestock system in the (sub) tropics [3] contributing about $74 \%$ of worldwide total CR [4]. Furthermore, CR need no additional allocation of water and land because they are byproducts of crops primarily grown for their principal product. Maize or corn (Zea mays) is the most producing crop in Asia and Africa after rice (paddy) and wheat [3]. Maize stover (MS) is estimated to be a contributor over a third of cereal CR production at the global level and for Africa as a whole, but more than $60 \%$ is in Latin America and 20\% in Asia [3]. Maize is currently produced on nearly 100 million ha in 125 developing countries and is among the three most widely grown crops in 75 of those countries [5]. At the global level, $63 \%$ of the demand for maize grain is now used for livestock feed to the extent of $70 \%$ in developed countries and 56\% in developing countries [6]. In Asia and Africa, maize is the most preferred cereal grain source in poultry diet $(60-70 \%)$ due to its high energy content and good palatability. The increasing demand for maize grain for feeding pig and poultry is at least 
regionally matched by increasing demand for MS as ruminant feedstuff [3,7]. In addition to this, price fluctuations in sorghum stover (a conventional roughage source) [8] increased the importance of MS inclusion as roughage source in ruminant diets.

Therefore, the present study was undertaken to optimize the MS to concentrate ratios in MS based completed diets for efficient microbial biomass production (EMBP) using in vitro gas production technique so as to recommend to the smallholder livestock farmers for suitable production.

\section{Materials and Methods}

\section{Ethical approval}

Experimental animals were handled as outlined by guidelines of Institutional Animal Ethics Committee, College of Veterinary Science, Hyderabad, and Sri Venkateswara Veterinary University.

\section{Sample preparation}

MS and concentrate mixture (Table-1) were ground using cyclone mill having $1 \mathrm{~mm}$ screen. Experimental complete diets with roughage to concentrate ratio of 100:0, 90:10, 80:20, 70:30, 60:40, 50:50, 40:60, and 30:70 were formulated and $200 \mathrm{mg}$ of oven dried experimental complete diet samples were weighed in triplicate for in vitro gas evaluation. The chemical composition of maize stove and concentrate mixture are presented in Table- 2 .

\section{Collection of rumen liquor ( $R L$ ) and media preparation}

The media used for in vitro gas production technique was prepared using various solutions (distilled water - $10 \mathrm{ml}$; macro mineral solution - $5 \mathrm{ml}$; bicarbonate buffer - $5 \mathrm{ml}$; micro mineral solution - $0.25 \mu$; resazurin solution $-0.025 \mathrm{ml}$, and reduction solution $-0.06 \mathrm{ml}$ ) [9]. RL was collected from three Deccani rams using stomach tube fitted with a vacuum pump before offering morning feed. These animals were fed on chopped MS and supplemented concentrate mixture. Approximately $350 \mathrm{ml} \mathrm{RL}$ was collected from different depths and directions of the reticulorumen in a pre-warmed thermos flask and transferred to the laboratory and strained through pre-warmed (kept in incubator for overnight at $39^{\circ} \mathrm{C}$ ) 4 -fold muslin cloth and flushed with $\mathrm{CO}_{2}$. Rumen fluid-buffer media mixture prepared by mixing RL $(10 \mathrm{ml})$ and bicarbonate mineral distilled water mixture $(20 \mathrm{ml})$ under continuous flushing with $\mathrm{CO}_{2}$, then this media mixture was injected into pre-warmed $\left(39^{\circ} \mathrm{C}\right)$ glass syringes (Fortuna Optima, Germany) containing $200 \mathrm{mg}$ sample, after addition of media, glass syringes were immediately transferred into water bath $\left(39^{\circ} \mathrm{C}\right)$ and incubated for $24 \mathrm{~h}$.

\section{Measurement of in vitro parameters}

The gas production was recorded at 8 and $24 \mathrm{~h}$ of incubation. After corrected for blank and standard, the gas production at $24 \mathrm{~h}$ was used to determine the metabolizable energy (ME) [6] and in vitro organic matter digestibility (IVOMD) [10]. Truly digestible
Table-1: Ingredient composition of the concentrate mixture.

\begin{tabular}{lc}
\hline Ingredient & \% \\
\hline Maize & 31.0 \\
Groundnut cake & 16.5 \\
Sunflower cake & 20.0 \\
Deoiled rice bran & 23.0 \\
Molasses & 5.0 \\
Urea & 1.5 \\
Mineral mixture & 2.0 \\
Salt & 1.0 \\
\hline
\end{tabular}

Table-2: Chemical composition (\% DM basis) of experimental feeds and complete diets.

\begin{tabular}{lcc}
\hline Parameter & $\begin{array}{c}\text { Maize } \\
\text { stover (\%) }\end{array}$ & $\begin{array}{c}\text { Concentrate } \\
\text { mixture (\%) }\end{array}$ \\
\hline DM & 90.5 & 89.5 \\
Organic matter & 88.59 & 89.65 \\
Crude protein & 5.51 & 20.52 \\
Crude fiber & 30.99 & 16.89 \\
Ether extract & 2.39 & 1.82 \\
Nitrogen free extract & 49.69 & 49.33 \\
Total ash & 11.41 & 10.35 \\
NDF & 77.93 & 27.19 \\
Acid detergent fiber & 43.23 & 18.21 \\
Hemicellulose & 34.72 & 9.32 \\
Cellulose & 35.83 & 13.51 \\
Lignin & 6.51 & 3.89 \\
\hline
\end{tabular}

Each value is average of three observations. NDF=Neutral detergent fiber, DM=Dry matter

organic matter (TDOM) is estimated by refluxing the residue of substrate left in the syringe after termination of incubation $(24 \mathrm{~h})$ with a neutral detergent solution and estimating neutral detergent fiber (NDF) in the undigested residue. The difference between the organic matter in the substrate before incubation and NDF in the undigested residue gives TDOM. The ratio of TDOM and gas volume produced $(24 \mathrm{~h}$ ) was used to know the partitioning factor (PF) [11]. The MBP and EMBP were calculated as described by Blümmel et al. [12] considering a stoichiometric factor 2.20. Ammonia nitrogen [13] and total VFA (TVFAs) [14] production were analyzed in RL fluid-media mixture after $24 \mathrm{~h}$ of incubation. Feed samples were analyzed for proximate principles [15] and fiber fractions [16].

\section{Statistical analysis}

The data obtained in this study were subjected to one-way analysis of variance. The differences between the means were tested for significance using Duncan's multiple range test [17]. All the statistical procedures carried out using Statistical Package for Social Sciences $16^{\text {th }}$ version.

\section{Results}

In vitro gas production, IVOMD, TDOM, and ME values were increased $(\mathrm{p}<0.01)$ linearly as increasing the proportion of concentrate $(0-70 \%)$ in complete diets (Table-3). Similarly, concentrate inclusion in complete diets increased $(p<0.01)$ the TVFA 
$(\mathrm{mEq} / \mathrm{L})$ (Table-3) and rumen ammonia nitrogen production $(\mathrm{mg} / 100 \mathrm{ml})$ (Table-4). Whereas, highest $(p<0.01)$ PF, MBP, and EMBP were noticed at 60R:40C and 50R:50C (Table-4) ratio compared to other combinations.

\section{Discussion}

\section{Gas production and organic matter digestibility}

Gas production $(\mathrm{ml} / 200 \mathrm{mg})$, which reflects the apparent substrate degradability [18], was increased $(\mathrm{p}<0.01)$ linearly in accordance with the proportion of concentrate $(0-70 \%)$ in the inoculum. Significantly $(p<0.01)$ highest and lowest gas production was recorded at 30R:70C and 100R:0C, respectively (Table-3). This increase in gas production with increased concentrate proportion in the inoculum, might be due to increase in the nutrient availability from concentrate [19] or might be due to lowered cell wall and lignin content in the inoculum as reduction in roughage proportion in the inoculum, which negatively affect the microbial attachment to the feed particles $[20,21]$. Similar to our results, previous researchers [22-24] also observed an increase in gas volume as a proportion of roughage was replaced by concentrate in the complete ration.

Similar to gas production, IVOMD, TDOM, and ME values were increased linearly as the concentrate proportion increased from $0 \%$ to $70 \%$ (Table- 3 ). The increased values might be due to gradual reduction in hemicellulose, cellulose, and lignin content in inoculum from 100R:0C to $30 \mathrm{R}: 70 \mathrm{C}$ which act as limiting factors to lower the digestibility at excess amount $[20,21]$ or increased nutrient availability to microorganisms from increased proportion of concentrate in the ration [19]. Similarly, Polyorach et al. [25] observed an increase in IVOMD in complete rations by increasing the concentrate proportion from $20 \%$ to $80 \%$. The results of the present study were also in agreement with Blümmel et al. [26] and Khanum et al. [27], who stated that CR digestibility can be improved when $\mathrm{CR}$ are supplemented with concentrate which provides better nutrients to microorganisms than roughage alone. Similarly, TVFA $(\mathrm{mEq} / \mathrm{L})$ production was also increased $(\mathrm{p}<0.01)($ Table- 3$)$ as the level of concentrate increased in the complete diet. This result is inconsistent with the findings of Getachew et al. [28], who concluded that TVFA production was positively correlated $(\mathrm{p}<0.01)$ with in vitro gas production.

\section{Ammonia production and microbial biomass synthesis}

The rumen ammonia nitrogen concentration increased $(p<0.01)$ linearly as increasing the concentrate proportion in the complete diet. Significantly $(p<0.01)$ highest and lowest ammonia nitrogen concentration was noticed with the rations containing $70 \%$ and $0 \%$ concentrates. This ammonia nitrogen increased in proportion to the concentrate in complete diet might be due to active degradation of protein and hydrolysis of non-protein nitrogen substances. Similar to our results, Kumari et al. [22] and Reddy et al. [24] observed increase in ammonia nitrogen concentration in complete diets having more

Table-3: Effect of MS to concentrate ratio on in vitro gas production parameters in Deccani sheep.

\begin{tabular}{|c|c|c|c|c|c|}
\hline Roughage:Concentrate & $\begin{array}{l}\text { Gas volume } \\
(\mathrm{ml} / 200 \mathrm{mg})\end{array}$ & $\begin{array}{l}\text { IVOMD } \\
\text { (mg) }\end{array}$ & $\begin{array}{c}\text { ME } \\
(M J / k g D M)\end{array}$ & $\begin{array}{l}\text { TDOM } \\
\text { (mg) }\end{array}$ & $\begin{array}{c}\text { TVFA } \\
(\mathrm{mEq} / \mathrm{L})\end{array}$ \\
\hline 100:0 & $43.00^{\mathrm{g}}$ & $94.60^{\mathrm{g}}$ & $8.15^{d}$ & $123.53^{9}$ & $26.33^{c}$ \\
\hline $90: 10$ & $44.00^{e f}$ & $96.80^{\mathrm{ef}}$ & $8.32^{\mathrm{cd}}$ & $131.86^{f}$ & $26.00^{c}$ \\
\hline $80: 20$ & $45.00^{e f}$ & $99.00^{\mathrm{ef}}$ & $8.50^{\mathrm{cd}}$ & $140.70^{e}$ & $26.00^{c}$ \\
\hline $70: 30$ & $45.83^{\text {de }}$ & $100.83^{\text {de }}$ & $8.62^{\mathrm{bcd}}$ & $146.09^{d}$ & $31.33^{b}$ \\
\hline $60: 40$ & $47.50^{\mathrm{cd}}$ & $104.50^{\mathrm{cd}}$ & $8.85^{b c}$ & $153.51^{\mathrm{c}}$ & $37.67^{a}$ \\
\hline $50: 50$ & $48.17^{b c}$ & $105.97^{b c}$ & $9.00^{\mathrm{abc}}$ & $154.42^{c}$ & $40.33^{a}$ \\
\hline $40: 60$ & $49.83^{b}$ & $109.63^{b}$ & $9.26^{\mathrm{ab}}$ & $157.78^{b}$ & $36.00^{a}$ \\
\hline $30: 70$ & $52.50^{a}$ & $115.50^{a}$ & $9.62^{a}$ & $160.67^{a}$ & $37.00^{a}$ \\
\hline SEM & 0.65 & 1.42 & 0.12 & 2.58 & 1.52 \\
\hline
\end{tabular}

Values bearing different superscripts in a column differ significantly $(p<0.01)$. IVOMD $=$ In vitro organic matter digestibility, ME=Metabolizable energy, TDOM=Truly digestible organic matter, TVFA=Total volatile fatty acids

Table-4: Effect of MS to concentrate ratio on PF, EMBP, and ammonia-nitrogen in Deccani sheep.

\begin{tabular}{lcccc}
\hline Roughage:Concentrate & Ammonia N ( $\mathbf{~ g / 1 0 0 ~} \mathbf{~ m I})$ & PF & MBP (mg) & EMBP (\%) \\
\hline $100: 0$ & $17.07^{\mathrm{a}}$ & $2.87^{\mathrm{d}}$ & $28.93^{\mathrm{d}}$ & $23.43^{\mathrm{d}}$ \\
$90: 10$ & $22.40^{\mathrm{f}}$ & $3.00^{\mathrm{cd}}$ & $35.06^{\mathrm{c}}$ & $26.59^{\mathrm{c}}$ \\
$80: 20$ & $25.87^{\mathrm{e}}$ & $3.13^{\mathrm{abc}}$ & $41.70^{\mathrm{b}}$ & $29.62^{\mathrm{ab}}$ \\
$70: 30$ & $30.13^{\mathrm{d}}$ & $3.19^{\mathrm{ab}}$ & $45.25^{\mathrm{ab}}$ & $30.98^{\mathrm{ab}}$ \\
$60: 40$ & $32.53^{\mathrm{d}}$ & $3.23^{\mathrm{a}}$ & $49.01^{\mathrm{a}}$ & $31.92^{\mathrm{a}}$ \\
$50: 50$ & $40.00^{\mathrm{c}}$ & $3.21^{\mathrm{a}}$ & $48.45^{\mathrm{a}}$ & $31.38^{\mathrm{a}}$ \\
$40: 60$ & $45.87^{\mathrm{b}}$ & $3.17^{\mathrm{ab}}$ & $48.15^{\mathrm{a}}$ & $30.53^{\mathrm{ab}}$ \\
$30: 70$ & $56.00^{\mathrm{a}}$ & $3.06^{\mathrm{bc}}$ & $45.17^{\mathrm{ab}}$ & $28.11^{\mathrm{bc}}$ \\
SEM & 2.53 & 0.02 & 1.47 & 0.63 \\
\hline
\end{tabular}

Values bearing different superscripts in a column differ significantly $(p<0.01)$. PF=Partitioning factor, MBP=Microbial biomass production, EMBP=Efficiency of microbial biomass production, $\mathrm{SEM}=$ Standard error of mean, MS=Maize stover 
concentrate proportion. During incubation, the liberated ammonia will be incorporated into microbial protein synthesis, but this incorporation depends on synchronization between availability of nitrogen and energy [29]. In the current study, though the ammonia nitrogen was the highest at 30R:70C, but the highest MBP synthesis was recorded at 60R:40C, 50R:50C, and 40R:60C (Table-4). This might be due to synchronization between liberated ammonia and availability of fermentable carbohydrates to the rumen bacteria. Similar to our results, Kumari et al. [22] and Reddy et al. [24] observed higher $(\mathrm{p}<0.01)$ MBP synthesis with 60R:40C, 50R:50C in complete diets though they noticed the highest ammonia production at 30R:70C. $\mathrm{PF}$ is an index for distribution of substrate truly degraded between microbial mass and fermentation products [30]. Therefore, PF provides meaningful information for prediction of MBP and also voluntary intake in ruminants. Similarly, Thirumalesh and Krishnamoorthy [30] noticed a positive correlation between microbial biomass flow to duodenum and PF of the total mixed ration. In the present investigation, higher $(\mathrm{p}<0.01)$ PF was noticed at 60R:40C, 50R:50C followed by at $70 \mathrm{R}: 30 \mathrm{C}$ and $40 \mathrm{R}: 60 \mathrm{C}$. The higher EMBP was also observed at 60R:40C, 50R:50C followed by at 70R:30C and 40R:60C, which was positively correlated with $\mathrm{PF}$ of the ration as has been reported previously $[22,24]$.

\section{Conclusion}

Based on the results, it was concluded that MS can be included between $50 \%$ and $60 \%$ level in complete rations for the economic rearing of ruminant animals.

\section{Authors' Contributions}

YRR and NNK implemented the study design. YRR, NNK, TM, and KS recorded the data and analyzed. NNK and KS drafted the manuscript. YRR, NNK, TM, and KS revised the manuscript. All authors read and approved the final manuscript.

\section{Acknowledgments}

The authors are thankful to the authorities of National Agricultural Innovation Project, Indian Council of Agricultural Research, New Delhi, India, for providing financial assistance to carry out this investigation. Appreciation is expressed to staff members of the College of Veterinary Science, Hyderabad, for their cooperation and support for smooth conduct of this study.

\section{Competing Interests} interests.

The authors declare that they have no competing

\section{References}

1. Shinde, A.K. and Sejian, V. (2013) Sheep husbandry under changing climate scenario in India: An overview. Indian $J$. Anim. Sci., 83: 998-1008.
2. Walli, T.K., Garg, M.R. and Makkar, H.P. (2012) Crop Residue Based Densified Total Mixed Ration. Food and Agriculture Organization of the United Nations, Rome, Italy.

3. Erenstein, O., Samaddar, A., Teufe, N. and Blümmel, M. (2011) The paradox of limited maize stover use in India's smallholder crop-livestock systems. Exp. Agric., 47: 677-704.

4. Lal, R. (2005) World crop residues production and implications of its use as a biofuel. Environ. Int., 31: 575-584.

5. FAOSTAT. (2010) Statistical Databases and Data-sets of the Food and Agricultural Organization of the United Nations, Rome, Italy. Available from: http://www.faostat.fao.org/ default.aspx. Accessed on 14-06-2012.

6. Shiferaw, B., Prasanna, B.M., Hellin, J. and Banziger, M. (2011) Crops that feed the world 6. Past successes and future challenges to the role played by maize in global good security. Food Secur, 3: 307-327.

7. Berhanu, T., Habtamu, Z., Friesen, D., Blümmel, M. and Twumasi-Afriyie, S. (2013) Relationship between the performance of parental inbread lines and hybrids for food-feed traits in maize in Ethiopia. Field Crops Res., (153): 86-93.

8. Blümmel, M., Tarawali, S.A., Teufel, N. and Wright, I.A. (2010) Dual-purpose crop developments, fodder trading and feed processing options for improving feeding in small holder dairy systems. Invited Paper of the 2010 International Dairy Conference. Mymensing, Bangladesh; 2010.

9. Menke, K.H. and Steingass, H. (1988) Estimation of the energetic feed value obtained from chemical analysis and in vitro gas production using rumen fluid. Anim. Res. Dev., 28: 7-55.

10. Krishnamoorthy, U., Rymer, C. and Robinson, P.H. (2005) The in vitro gas production technique: Limitations and opportunities. Anim. Feed Sci. Technol., 123: 1-7.

11. Blümmel, M., Steingas, H. and Becker, K. (1994) The partitioning of in vitro fermentation products and its bearing for voluntary feed intake. In: Proceedings of the Society of Nutrition Physiology, Germany. p123.

12. Blümmel, M., Steingas, H. and Becker, K. (1997) The relationship between in vitro gas production, in vitro microbial biomass yield and $\mathrm{N}$ incorporation and its implications for the prediction of voluntary feed intake of roughages. $\mathrm{Br} . J$. Nutr., 77: 911-921.

13. Conway, E.J. (1957) Micro Diffusion Analysis and Volumetric Error. $4^{\text {th }}$ ed. Crosby Lockwood and Son, Ltd., Publishers, London, UK.

14. Barnett, A.J. and Reid, R.C. (1956) Studies on the production of volatile fatty acids from the grass by rumen liquor in an artificial rumen VFA production from grass. J. Agric. Sci., 48: 131-161.

15. AOAC. (2005) Official Methods of Analysis. $19^{\text {th }}$ ed. Association of Official Analytical Chemists, Maryland, USA.

16. Van Soest, P.V., Robertson, J.B. and Lewis, B.A. (1991) Methods for dietary fiber, neutral detergent fiber and nonstarch polysaccharides in relation to animal nutrition. $J$. Dairy Sci., 74: 3583-3597.

17. Duncan, D.B. (1955) Multiple range and multiple F tests. Biometrics, 11(1): 1-42.

18. Pashaei, S., Razmar, V. and Mirshekar, R. (2010) Gas production: A proposed in vitro method to estimate the extent of digestion of feedstuff in the rumen. J. Biol. Sci., 10: $573-580$.

19. Ahmed, G.N. and Abdel, N.M. (2007) Chemical composition and in vitro gas production characteristics of six fodder trees leaves and seeds. J. Agric. Biol. Sci., 3: 983-986.

20. Frei, M. (2013) Lignin: Characterization of a multifaceted crop component. Sci. World J., 2013: 1-25.

21. Al-Masri, M.R. (2009) An in vitro nutritive evaluation and rumen fermentation kinetics of Sesbania aculeata as affected by harvest time and cutting regimen. Trop. Anim. Health Prod., 41: 1115-1126.

22. Kumari, N.N., Reddy, Y.R., Blummel, M. and Monika, T. 
(2012) Optimization of roughage to concentrate ratio in sweet sorghum bagasse based complete ration for efficient microbial biomass production in sheep using in vitro gas technique. Int. J. Pharm. Biol. Sci., 3: 247-257.

23. Seshaiah, C.V., Reddy, Y.R., Rao, S.J. and Srivani, M. (2014) Prediction of optimum roughage to concentrate ratio in sweet sorghum (Sorghum bicolor L. Moench) bagasse based total mixed ration for buffaloes using in vitro gas technique. J. Adv. Vet. Anim. Res., 1: 224-227.

24. Reddy, Y.R., Kumari, N.N., Monika, T., Pavani, M. and Sridhar, K. (2015) Evaluation of sorghum stover based complete rations with different roughage to concentrate ratio for efficient microbial biomass production by using in vitro gas production technique. J. Anim. Res., 5: 47-52.

25. Polyorach, S., Wanapat, M. and Cherdthong, A. (2014) Influence of yeast fermented cassava chip protein (yefecap) and roughage to concentrate ratio on ruminal fermentation and microorganisms using in vitro gas production technique. Asian-Aust. J. Anim. Sci., 27: 36-41.

26. Blümmel, M., Rao, S.S., Palaniswami, S., Shah, L. and
Reddy, B.V.S. (2009) Evaluation of sweet sorghum (Sorghum bicolor L. Moench) used for bio - Ethanol production in the context of optimizing whole plant utilization. Anim. Feed Sci. Technol., 9: 1-10.

27. Khanum, S.A., Yaqoob, T., Sadaf, S., Hussain, M. and Jabbar, M.A. (2007) Nutritional evaluation of various feedstuffs for livestock production using in vitro gas method. Pak. Vet. J., 27: 129-133.

28. Getachew, G., Robinson, P.H., De Peters, E.J. and Taylor, S.J. (2004) Relationships between chemical composition, dry matter degradation and in vitro gas production of several ruminant feeds. Anim. Feed Sci. Technol., 111: 57-71.

29. Thirumalesh, T. and Krishnamoorthy, U. (2013) Rumen microbial biomass synthesis and its importance in ruminant production. Int. J. Livest. Res., 3: 5-26.

30. Thirumalesh, T. and Krishnamoorthy, U. (2009) Effect of feeding diets differing in partitioning factor (PF) on intake, digestibility and nitrogen metabolism in ram lambs. Anim. Nutr. Feed Technol., 9: 11-20.

$* * * * * * * *$ 